\title{
The Effect of Latitude Differences, Sunshine Periods, Solar Radiation Quantities and Air Temperatures on Solar Electricity Generation
}

\author{
Ali Samet SARKIN and Taner DİNDAR
}

\begin{abstract}
Electricity supply has gained importance with the increase of electricity demand in the world. The energy that the sun can accept forever provides great convenience for electricity generation. In regions where the sun's rays are steep, it is easier to generate electricity from the solar energy, whereas in regions where the sun's rays are horizontal, the electricity production from the solar energy remains at a lower level. In this study, Istanbul and Adana are compared in the northern and southern regions of Turkey. These two cities were examined for daily sunshine periods, daily and monthly radiation amounts. The effects of air temperatures and sunshine durations on the average radiation amounts have been investigated. The province of Adana has an annual total of $1568.49 \mathrm{kWh}$, whereas the province of Istanbul has a total of $1327 \mathrm{kWh}$ radiation. When the annual sunshine periods are examined, it is $\mathbf{9 7 . 1 3}$ hours in Adana and 78.99 hours in Istanbul. It is seen that less electricity production can be done year round in Istanbul province and the hourly production is more than that in Adana when compared to sunrise times. When the average annual temperatures are examined, Adana province is $19{ }^{\circ} \mathrm{C}$ and Istanbul province is $13.8{ }^{\circ} \mathrm{C}$. Although the province of Istanbul has a lower average temperature, it has been found that it has a higher yield than the province of Adana.
\end{abstract}

Index Terms - Solar energy, temperature, radiation, insolation.

\section{INTRODUCTION}

$\mathrm{T}$ HE increase in world energy demands has led to the search for alternative energy productions. Electricity consumption in the world has reached 22.269 billion $\mathrm{kWh}$ by 2015 . Electricity consumption of Turkey has been reached up to 265 billion $\mathrm{kWh}$ as of 2015 [1]. In order to be able to meet the electricity consumption of these very high quantities, the world has been searching for alternative electricity energy production. Due to environmental pollution and harm to human health caused by fossil fuels, it has been directed towards renewable energy sources. 167 billion $\mathrm{kWh}(1 \%)$ of the world's electricity generation is generated by using solar energy. $40 \mathrm{MW}(0.06 \%)$ of Turkey's electricity is met by solar energy [2]. One of the renewable energy sources is the sun energy.

Manuscript received March 15, 2017; revised March 25, 2017; accepted April 23, 2017

Ali Samet SARKIN is with Osmaniye Korkut Ata Üniversitesi Kadirli MYO (corresponding author; e-mail: sametsarkin@ osmaniye.edu.tr).

Taner DINDAR is now with Ankara Üniversitesi Nallıhan MYO (e-mail: tdindar@ankara.edu.tr).
The sun is the energy source for the entire universe and transmits $1.5 \times 105 \mathrm{MWh}$ of energy to the Earth. This amount corresponds to 28,000 times the energy consumed in a year worldwide [3]. The amount of light from the sun on the Earth for 90 minutes is enough to cover the entire world's energy needs for one year [4]. In this sense, the sun is regarded as an infinitive source of energy for our world.

\section{SOLAR ENERGY}

The Sun which is the energy source of the Milky Way galaxy has a surface temperature of 8000 Kelvin. With the fusion process that takes place on the sun, the radiation is emitted to the earth and therefore to the earth. The solar radiation is 1366 Watt $/ \mathrm{m}^{2}$ in the world and $9116 \mathrm{Watt} / \mathrm{m}^{2}$ in Mercury, the closest planet to the Sun, and $0.878 \mathrm{Watt} / \mathrm{m}^{2}$ in Pluto, the planet farthest from the Sun. The value of $1366 \mathrm{Watt} / \mathrm{m}^{2}$ reaching the world is called solar energy constant [5]. The light that the sun sends to the Earth's atmosphere cannot reach the earth's crust. While $30 \%$ of this radiation cannot pass through the atmosphere, $20 \%$ is occupied by the atmosphere and clouds while $50 \%$ reaches the earth [6].

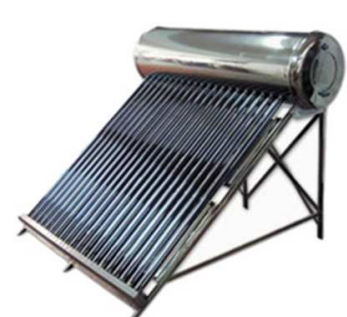

(a)

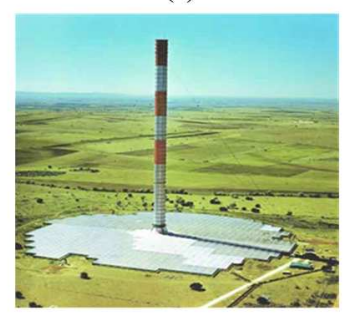

(c)

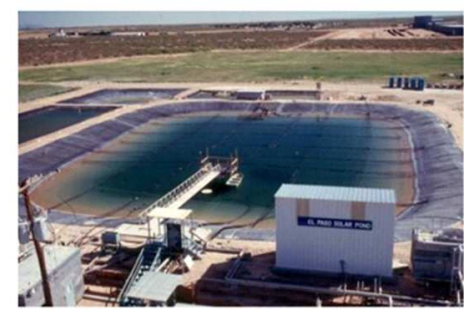

(b)

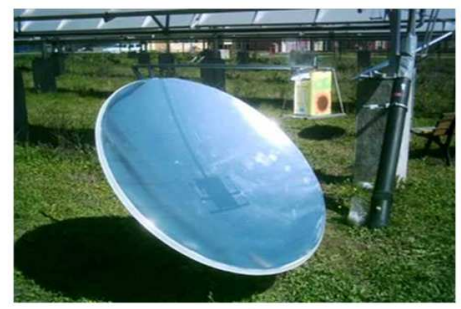

(d)
Fig.1. (a). Solar collectors, (b). Solar pools, (c). Solar chimney, (d). Solar cooker.

Due to the unique power of the sun, various applications have been developed to benefit from solar energy such as heat and electricity. These; Solar collectors, Solar pools, Solar chimneys, Water treatment systems, Product drying and greenhouses, Solar cookers and Photovoltaic solar cells [7]. 


\section{Photovoltaic (PV) Solar Cells AND Turkey's SOLAR ENERGY}

Photovoltaic solar cells convert solar heat directly into electrical energy, unlike other solar methods. In fact, photovoltaic solar cells fabricated from a semiconductor material cause a negative ion flux between the N-P poles in the semiconductor material and the heat generated by the sun's rays. With this continuous negative ion flow, electric current flows. Today, there are solar cell models that differ from each other in terms of production techniques such as Monocrystalline, Polycrystalline and Thin Film. They convert the sunlight coming on these models to electric energy at different rates. Monocrystalline cells are produced with $15-22.5 \%$, polycrystalline cells with $14-16 \%$, thin film with $9-11 \%$ yield [8].

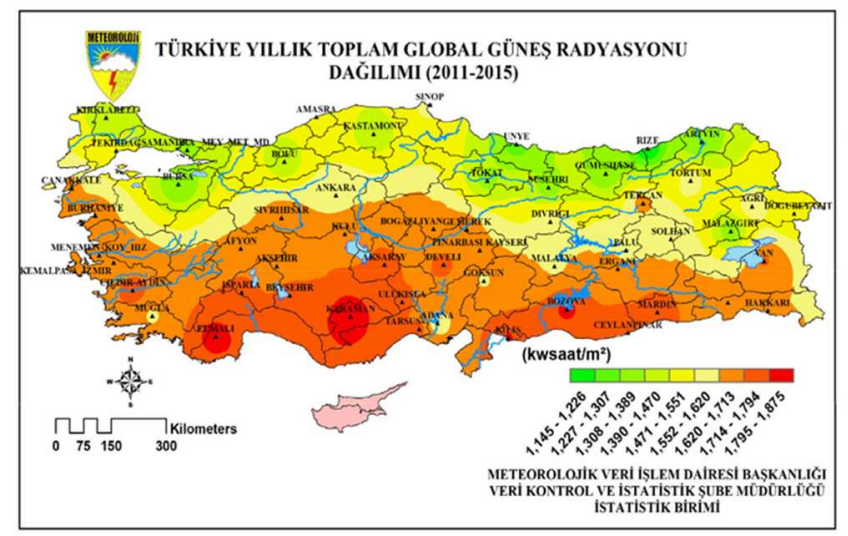

Fig.2. Turkey's Annual Total Solar Radiation Distribution [9].

Regardless of the manufacturing power of the solar cells, the amount of instantaneous electric current that they produce determines the amount of sunlight, daily light period, monthly and yearly lighting periods, cloudiness rate. The change of these factors determines the latitude and longitude of a place. As can be seen from Fig.2, the north, middle and southern generations of Turkey are exposed to solar radiation in different quantities. In this study, research was carried out on whether each generation would produce different power if it had the same conditions. Turkey has an average annual solar radiation of $4,175 \mathrm{kWh} / \mathrm{m}^{2}$. Turkey's average annual sunshine duration is 7,498 hours. The annual average temperature value is $13.1^{\circ} \mathrm{C}$ [10].

Turkish government has introduced some incentives in order to obtain electricity from solar energy and has increased these incentives [11]. Along with these incentives, in 2015, the number of power plants generating unlicensed electricity from solar energy reached 673 and the installed power reached 505.9 MW [12]. In recent years, with solar energy investments in Turkey, only $0.06 \%$ of the country's electricity is covered by photovoltaic solar panels.

\section{METHOD AND RESEARCH}

In this study, the effects of solar radiation and the amount of heat on the electricity production between southern and northern generations of Turkey are discussed. The city of Istanbul was taken as an example for the northern belt while the city of Adana was taken as an example for the southern belt. Latitude differences in these cities will also affect the annual and monthly temperature ratings and sunshine duration.
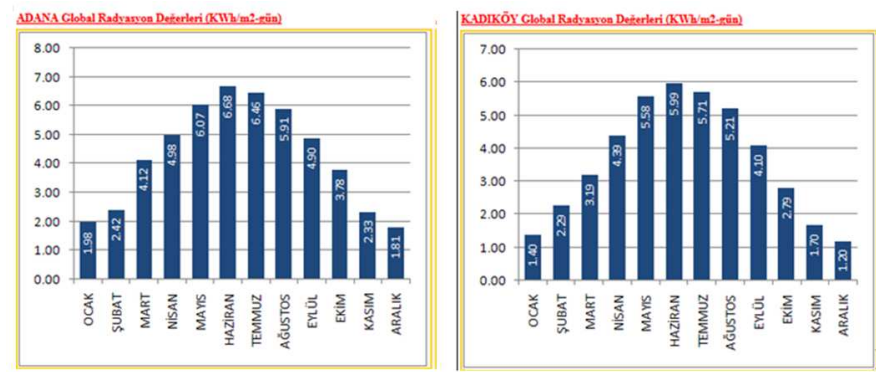

Fig.3. Monthly radiation values of Adana and Istanbul [13].

As shown in Fig.3, the southern belt of Adana province receives quite good solar radiation throughout the year. These values may vary depending on clouds, rainfall, air pollution, shading, and surface inclination. Measured values are measured according to normal ambient conditions and horizontal adjustment.
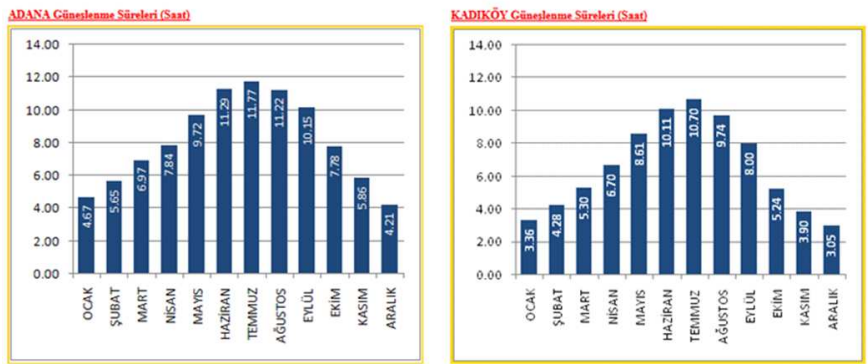

Fig. 4. Monthly sunshine periods for Adana and Istanbul [13].

Fig.4 shows the light periods of Adana in the southern belt and Istanbul in the northern belt according to the month. Adana province is exactly 37.00. Istanbul on the latitude found 41.00 . It is located on the latitude. These 4 latitude differences affect both solar times and affect solar radiation values taken yearround.

TABLE I. COMPARISON OF SOLAR RADIATION VALUES, SUNRISE TIMES AND HOURLY EFFICIENCY OF ADANA AND ISTANBUL PROVINCES

\begin{tabular}{|l|c|c|c|c|c|c|c|c|}
\hline & $\begin{array}{c}\text { Solar Radiation Values } \\
\text { (Kwh/m2-day) }\end{array}$ & \multicolumn{2}{c|}{$\begin{array}{c}\text { Solar Radiation Values } \\
\text { (Kwh/m2-day) }\end{array}$} & \multicolumn{2}{c|}{$\begin{array}{c}\text { Sunshine Times } \\
\text { (hours-day) }\end{array}$} & \multicolumn{2}{c|}{$\begin{array}{c}\text { Daily Radiation by } \\
\text { Sunrise (Kwh/m } / \text { day) }\end{array}$} \\
\cline { 2 - 8 } & Adana & İstanbul & Adana & İstanbul & Adana & İstanbul & Adana & İstanbul \\
\hline Ocak & 1,98 & 1,40 & 61,38 & 43,4 & 4,67 & 3,36 & 0,423983 & 0,416667 \\
\hline Feb. & 2,42 & 2,29 & 67,76 & 64,12 & 5,65 & 4,28 & 0,428319 & 0,535047 \\
\hline March & 4,12 & 3,19 & 127,72 & 98,89 & 6,97 & 5,30 & 0,591105 & 0,601887 \\
\hline April & 4,98 & 4,39 & 149,4 & 131,7 & 7,84 & 6,70 & 0,635204 & 0,655224 \\
\hline May & 6,07 & 5,58 & 188,17 & 172,98 & 9,72 & 8,61 & 0,624486 & 0,648084 \\
\hline June & 6,68 & 5,99 & 200,4 & 179,7 & 11,29 & 10,11 & 0,591674 & 0,592483 \\
\hline July & 6,46 & 5,71 & 200,26 & 177,01 & 11,77 & 10,70 & 0,548853 & 0,533645 \\
\hline Aug. & 5,91 & 5,21 & 183,21 & 161,51 & 11,22 & 9,74 & 0,526738 & 0,534908 \\
\hline Sept. & 4,90 & 4,10 & 147 & 123 & 10,15 & 8,00 & 0,482759 & 0,5125 \\
\hline Oct. & 3,78 & 2,79 & 117,18 & 86,49 & 7,78 & 5,24 & 0,485861 & 0,532443 \\
\hline Nov. & 2,33 & 1,70 & 69,9 & 51 & 5,86 & 3,90 & 0,397611 & 0,435897 \\
\hline Dec. & 1,81 & 1,20 & 56,11 & 37,2 & 4,21 & 3,05 & 0,429929 & 0,393443 \\
\hline
\end{tabular}

In Table 1, daily solar radiation values between Istanbul, which is located in the northern belt, and Adana, which is located in the southern belt, are taken. These values were taken over the calendar days (January 31, February 28) as months. When Adana and Istanbul are compared only in terms of solar radiation, Adana province receives more solar radiation than 
İstanbul in all months of the year. This is because of the number of active sunshine hours that can be actively generated from the latitude and latitude of sunshine. Higher radiation values can be obtained in areas with longer sunshine duration.

Considering the sunshine periods of Adana and Istanbul all year round, it is seen that Adana has more sunshine period every month than İstanbul. Moreover, the region of Adana stands out as a very suitable region for the application of solar panels with sufficient illumination to produce electricity for almost 12 hours in June, July, August and September. Istanbul has a significant disadvantage in that it has very limited implementation time to generate electricity from solar energy in January, February, March, October, November and December. Adana province has 97 hours of sunshine yearly and 79 hours of Istanbul province has suitable solar power for electricity generation.

TABLE II. MONTHLy AVERAGE TEMPERATURES IN ADANA AND İSTANBUL [14]

\begin{tabular}{|l|c|c|}
\hline & Andana $\left({ }^{\circ} \mathrm{C}\right)$ & Instanbul $\left({ }^{\circ} \mathrm{C}\right)$ \\
\hline Ocak & 9.6 & 5.7 \\
\hline February & 10.5 & 5.7 \\
\hline March & 13.5 & 7.0 \\
\hline April & 17.5 & 11.1 \\
\hline May & 21.7 & 15.7 \\
\hline June & 25.6 & 20.4 \\
\hline July & 28.1 & 22.9 \\
\hline August & 28.5 & 23.1 \\
\hline September & 25.9 & 19.8 \\
\hline October & 21.3 & 15.6 \\
\hline November & 15.5 & 11.5 \\
\hline December & 11.2 & 8.0 \\
\hline
\end{tabular}

If the sunshine periods are not taken into consideration, the southern belt province of Adana will produce $1568.49 \mathrm{kWh}$ of electricity in the area of 1 meter square, while Istanbul will produce $1327 \mathrm{kWh}$ electricity in the area of 1 square meter. However, when compared to the hours of sunshine, the rate of sunshine per hour is less than the duration of sunshine and sunshine in Istanbul, but it produces efficient electricity in the province of Adana in 9 months of the year. However, there is a $15.4 \%$ decrease in the amount of electricity to be produced at the end of the year due to the shortage of sunshine. The reason why Adana produces electricity more efficiently from Istanbul per hour in December, January and July is the difference between the average monthly temperature values shown in Table II because it produces less electricity for 9 months. High temperatures are known to reduce the efficiency of panels. Power generation is reduced by approximately $0.5 \%$ at every 1 ${ }^{\circ} \mathrm{C}$ day of air temperature [15].

According to the monthly solar radiation values, Adana is the highest month with $200 \mathrm{Kwh}$ in July and June and $56 \mathrm{kWh}$ in December, which is the lowest production, can produce almost 4 times as much electricity. In the province of Istanbul, electricity can be produced 4-5.5 times more than December and January when the highest production is realized in 170-180 $\mathrm{Kwh}$ in May, June and July and $40 \mathrm{Kwh}$ in lowest production.

\section{CONCLUSION}

It has been accepted that the electrical factors such as inverter efficiency and solar cell yield are the same for both sample cities as well as side factors such as cloudiness level, rain, fog, horizontal and inclined plane, and the same panels are used. Adana and Istanbul have a sunshine duration of 97 hours in Adana province and 79 hours in Istanbul province in terms of sunshine periods. It has been observed that Adana province has an enlightenment of $22 \%$ more than Istanbul in the year-round total.

Adana province under the influence of the southern generation has a potential to produce $1327 \mathrm{kWh}$ from the province of Istanbul located on the northern belt and $18.20 \%$ more electricity by the end of the year at $1568.49 \mathrm{kWh}$. This difference is influential on the return period of the direct investment. At the same time, it increases the initial installation costs by $20 \%$. More power may be required on the unit surface to achieve the same amount of power. The use of more panels in the other direction will also increase cabling and labor costs.

In Table I, Istanbul's air temperature is between $10-15^{\circ} \mathrm{C}$ in April and May, which is the most productive month in terms of panel efficiency. In Table II, in December and January, when the average temperature of Adana is $10-15{ }^{\circ} \mathrm{C}$, the month is the highest in terms of panel efficiency. From there, the effect of panels on the temperature of the air can be seen. The fact that the high temperature values do not mean more electricity production is actually the optimal air temperature average for the panel is $10-15^{\circ} \mathrm{C}$.

When examined in terms of temperature, the province of Istanbul will not be able to change the current weather conditions, so it will be able to take maximum advantage of sunshine durations. However, the high temperatures in Adana have the potential to reduce the panel power. In other words, reducing the temperature of the panels' surfaces will increase the panel's power. More power production is available in Adana.

\section{REFERENCES}

[1] https://yearbook.enerdata.net/electricity-domestic-consumption-databy- region.html Date of access: 01.11.2016.

[2] 2015 Faaliyet Raporu, Enerji ve Tabii Kaynaklar Bakanlığı, Strateji Geliştirme Daire Başkanlığı, 2016, Ankara.

[3] Milges, Milhes, Milkanat ve YDGA sistemi Geliştirilmesi Projeleri, Enerji ve Tabii Kaynaklar Bakanlığı, 07.05.2015, Ankara.

[4] I. Kiziroğlu, Alternatif Enerji Kaynakları İnsanlığı Kurtaracak, Popüler Bilim Dergisi, 2005, 12, 50-54.

[5] http://rredc.nrel.gov/solar/spectra/am0/ASTM2000.html Date of access: 01.11.2016.

[6] http://www.eie.gov.tr/yenilenebilir/g_enj_tekno.aspx Date of access: 01.11.2016.

[7] Akçalı İ., Güneş Enerjisi Sistemleri, İstanbul Ticaret Odası, 2001.

[8] http://www.solarreviews.com/solar-energy/pros-and-cons-of-monocrystalline-vs-polycrystalline-solar-panels/.

[9] http://www.eie.gov.tr/MyCalculator/Default.aspx Date of access: 04.11.2016.

[10] Türkiye Ortalama Sicaklık, Meteoroloji Genel Müdürlüğü Resmi İstatistikler, 2015, Ankara. 
[11] Enerji ve Tabii Kaynaklar Bakanlığı ile Bağlı, İlgili ve İlişkili Kuruluşlarının Amaç ve Faaliyetleri, Enerji ve Tabii Kaynaklar Bakanlığı, Bağlı ve İlgili Kuruluşlar Dairesi Başkanlığı, 2015, Ankara.

[12] http://enerji.gov.tr/tr-TR/Sayfalar/Elektrik Date of access: 05.11.2016.

[13] http://www.eie.gov.tr/MyCalculator/pages/34.aspx Date of access: 05.11.2016.

[14] http://www.mgm.gov.tr/veridegerlendirme/il-ve-ilceler-istatistik.aspx Date of access: 08.11.2016.

[15] R. Rabinovici, A. Havili, O. Cohen, Y.B. Frechter, Predicting a Solar Field's Power Output, While Considering Environmental Conditions, 2010 IEEE 26-th Convention of Electrical and Electronics Engineers in Israel, 36-40, 2010.
Ali Samet Sarkın received his B.Sc. and M.Sc. degrees from Marmara University both in Electrical Engineering in 2013. Currently, he is pursuing $\mathrm{PhD}$ program at Marmara University. Since 2014, he has been working as a lecturer at Osmaniye Korkut Ata University. His interests are solar systems and energy efficiency.

Taner Dindar received his B.Sc. and M.Sc. degrees from Marmara University, Istanbul, Turkey in Electrical Engineering in 2009 and 2012 respectively. He is currently working at Ankara University, Ankara, Turkey. He worked as a lecturer in Arel University, Department of Electricity from 2011 to 2012 in Istanbul, Turkey. His research interest includes the high voltage systems, energy applications, and control systems. 